\title{
FIRST DATA ON AQUATIC MITES (ACARI) OF INLAND WATER BODIES OF WEST SPITSBERGEN, SVALBARD
}

\author{
Elena S. Chertoprud ${ }^{1,2}$, Olga L. Makarova ${ }^{2}$ and Anna A. Novichkova ${ }^{1,2}$
}

${ }^{1}$ Lomonosov Moscow State University, Biological Faculty, Moscow, Russia

${ }^{2}$ Severtsov Institute of Ecology and Evolution, Russian Academy of Sciences, Moscow, Russia

*corresponding author; e-mail: ol_makarova@mail.ru

\begin{abstract}
This paper presents the first results of a study on the aquatic mites (Acari) from the inland water bodies of West Spitsbergen, Svalbard. Six mite species have been found: namely, the oribatids Camisia foveolata Hammer, 1955 and Ameronothrus lineatus (Thorell, 1871); the gamasid mite Halolaelaps sp.; as well as the halacarids Halacarellus sp., Isobactrus levis (Viets, 1927) and Rhombognathides spinipes (Viets, 1933). The latter two species are new to the fauna of Svalbard. No true freshwater mites (Hydrachnidia) have been identified. A preliminary comparison of the inland aquatic acarofauna of Svalbard with the fauna of other Arctic regions has been conducted. The entire halacarid mite fauna of Svalbard (13 species), including both inland water species and true marine ones from the surrounding seas, can be characterized as rather regionally specialized and mainly cryophilic.
\end{abstract}

KEY WORDS: Halacaridae, Oribatida, Mesostigmata, new records, geographical range, High Arctic, amphibious species, euryhaline species, freshwater species.

DOI: 10.21684/0132-8077-2017-25-2-181-189

\section{INTRODUCTION}

Aquatic mites of the inland waters in the Arctic are still poorly known. They belong to two taxonomically remote groups of the suborder Prostigmata, order Trombidiformes, i.e. the "true" freshwater mites Hydrachnidia (cohort Parasitengonina) and the mostly marine mites of the family Halacaridae (cohort Eupodina). Parasitic larvae of Hydrachnidia feed on and are dispersed by insects, while deutonymphs and adult mites are predators. Most of the species of Halacaridae populate sea bottom habitats. Whereas freshwater forms are rather rare, euryhaline species are numerous. The family Halacaridae includes both phytophagous (mostly algophagous) and predatory forms (Bartsch 1989, 2008). Although a significant amount of data on freshwater mites of the Low Arctic is available (Viets 1928; Sokolov 1952; Habeeb 1957; Bartsch 1978, 2011; Semenchenko et al. 2010; Gerecke 2015), information on the faunas of the High Arctic areas is scarce (Bartsch 1978; Danks 1981; Gerecke 2015).

The Svalbard Archipelago is an internationally valuable and sensitive High Arctic area with a considerable amount of various water bodies. Freshwater and brackish habitats - such as springs, rivers, lakes, ponds, and lagoons - are numerous, covering about $2 \%$ of the total land area (Hisdal 1998). Most of the water bodies on the arctic islands are small, shallow (Janiec 1996), and can freeze solid in the winter (Pienitz et al. 2008). During the summer, there is an extensive development of micro-invertebrates whose diversity responds to the environmental variables controlled by the cli- mate (Coulson 2007; Coulson et al. 2014). However, the faunas of temporary pools, ditches, spring mosses and wetlands are insufficiently explored. Thus, the latest catalogues of terrestrial and freshwater invertebrates of Svalbard make no mention of water mites being present in the main part of the archipelago (Coulson and Refseth 2004; Coulson 2012). The same concerns the recent review of biodiversity of the Barents Sea archipelagoes (Coulson et al. 2014), although some data on the presence of brackish and freshwater mite species in West Spitsbergen have been published (Bartsch 1978, 2009). Bear Island, which is officially considered part of the Svalbard Archipelago, is known to support one hydrachnid species (references in Coulson and Refseth 2004).

The objective of the present study is, therefore, to fill the aforementioned lacuna. For the first time, we have focused on aquatic mites that inhabit various types of inland waters of Svalbard. This group often constitutes an important part of the species richness and abundance of arthropods in temporary and perennial freshwater, as well as brackish water bodies (Mokievsky 2009).

\section{MATERIAL AND METHODS}

Svalbard is composed of a group of islands, including West Spitzbergen (or Spitsbergen in Russian toponymy), which is the largest and the only permanently populated body of land on the archipelago. The survey was performed in the central and western parts of West Spitsbergen in 2014-2015 (Fig. 1). 


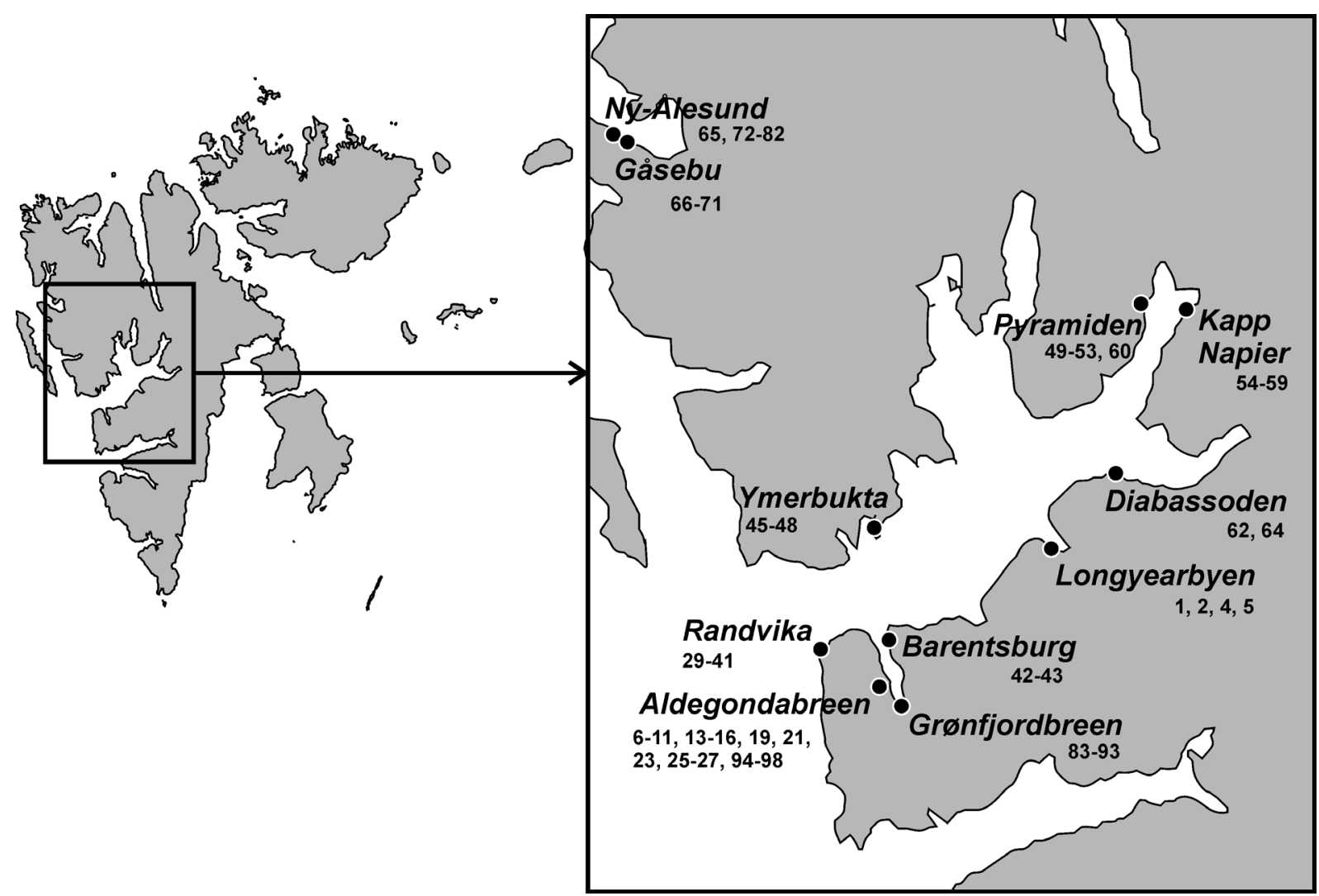

Fig. 1. Sampling localities on West Spitsbergen, Svalbard, in 2014 and 2015.

Climate. Svalbard lies within an area of interaction of the warm North Atlantic Current and the cold, ice-covered Arctic Ocean in the zone of a stable west-east transport of air masses (Dolgushin and Osipova 1989). The rate of annual precipitation on the west coast of Spitzbergen averages $500 \mathrm{~mm}$ (COAT). Positive air temperatures are usually observed for four months a year. The average temperature in the warmest months, July and August, is $4-6^{\circ} \mathrm{C}$. In winter, the mean monthly temperatures rarely rise above -12 to $-16{ }^{\circ} \mathrm{C}$, even on the west coast, which faces the warm waters of the West Spitsbergen Current (Nordli 2005).

Inland water bodies. Rivers in Svalbard feed on melting snow or glacial ice and usually originate on glaciers' edges (Pechurov 1983). The hydrological activity is characterized by considerable seasonal and daily flow fluctuations. The water in the rivers is very cold, with the summer temperatures of only a few degrees above zero. The rivers freeze solid in the winter and sometimes dry up during autumn.

There are relatively few large lakes in Svalbard, with the maximum linear size of more than $10 \mathrm{~km}$ (Hisdal 1998). However, there are numerous small shallow lakes (ponds) and puddles, with mostly stony bottoms, bounded with permafrost (Dol- gushin and Osipova 1989). Most of them freeze to the bottom in winter (Pienitz et al. 2008). Moreover, there are lots of coastal lake-like lagoons along the seashore (Coulson et al. 2014).

Study sites. Samples were taken between August $18^{\text {th }}$ and $24^{\text {th }}, 2014$ in the Isfjorden area alone, as well as between August $17^{\text {th }}$ and $22^{\text {nd }}, 2015$ both in the Isfjorden area and near the Ny-Ålesund Village (Kongsfjorden area). Sampling was conducted in different parts around Isfjorden [Longyearbyen (4 mixed samples), Aldegondabreen (21), Grønfjordbreen (11), Randvika (13), Barentsburg (2), Ymerbukta (4), Pyramiden (6), Kapp Napier (6), Diabassoden (2)] and Kongsfjorden [NyÅlesund (12) and Gåsebu (6)]. Altogether, 11 sampling localities were visited and 87 samples were taken from water bodies of various size and depth.

According to the size, sampling sites were categorized into four classes: puddles (area $<0.01 \mathrm{ha})-28$ sampling sites; small ponds (from 0.01 to $0.1 \mathrm{ha}$ ) -19 sampling sites; large ponds (from 0.1 to $1.0 \mathrm{ha}$ ) -18 sampling sites; lakes (more than $1 \mathrm{ha}$ )-17 sampling sites. In this survey, six oligo- or mesohaline lagoons were also studied, as well as the coastal zone of two large lakes: Linné Lake (surface area $4.6 \mathrm{~km}^{2}$ ) and Bretjørna Lake (surface area $1.3 \mathrm{~km}^{2}$ ). 
Aquatic mites were found only in six samples, whose general characteristics are presented in Table 1. Half of the samples were taken from the brackish puddles along the seashore, and the others were related to freshwater puddles on moraines in glacier areas.

Sampling and species identification. Samples were obtained from the shores of the water bodies. Three substrate portions were taken for each mixed sample. Meiobenthic samples were taken with a plastic tube ( $2 \mathrm{~cm}$ in diameter). A column of the upper sediment layer $(3-4 \mathrm{~cm})$ was pushed out from the tube with a plunger and preserved with $96 \%$ ethanol. Thus, sampling of aquatic mites was performed together with other groups of meiobenthos (Copepoda, Cladocera, Tardigrada and Nematoda). In addition, samples of zooplankton were taken using a net $(100 \mathrm{~mm}$ in diameter, $50 \mu \mathrm{m}$ in mesh size). However, mites in the net catches were totally absent.

As for the primal sample treatment, the sediment patterns were washed with filtered fresh water through a gauze net with a $50 \mu \mathrm{m}$ mesh. The arthropods were out of the residual matter in Bogorov's counting chambers under a stereo microscope with $32^{\mathrm{x}}$ magnification. Iodine alcohol solvent coloring was used in order to recognize the organisms more easily.

The mites were mounted on permanent slides using Hoyer's medium. Their identification was conducted with light microscopy at 200-400 ${ }^{\mathrm{x}}$ magnifications. The following handbooks were used:
Sokolov (1952), Blaszak and Ehrnsberger (1998), Weigmann (2006), Bartsch (2006a, b) and Makarova (2015a). The slides with mounted mite specimens of all recovered species, as well as the main part of the material on oribatid Camisia foveolata Hammer, 1955 (58 specimens in 96\% alcohol) have been deposited in the Natural History Museum, University of Oslo, Sars Gate 1, NO-0562 Oslo, Norway.

\section{RESULTS}

A total of six species of Acari were found in the present survey (Table 2), namely, two oribatid species, one gamasid and three prostigmatic mite species. The latter trio belongs to the mainly marine family Halacaridae. Two halacarid species are new to the Svalbard fauna. No true freshwater mites (Hydrachnidia) have been identified in the water bodies of Svalbard.

Most mite species were observed in a single water body (i.e., one species per water body), and were represented only by a few specimens. This is very distinct from the situation with meiobenthic crustaceans in the same material. The latter were recorded in $94 \%$ of the samples numbering more than 5,000 specimens in total.

\section{DISCUSSION}

The fauna of aquatic mites in the European sector of the Arctic (Viets 1928; Sokolov 1952; Bartsch 1978, 2009) and Greenland (Gerecke 2015)

Table 1

Characteristics of the samples from Spitsbergen where aquatic mites were found

\begin{tabular}{|l|l|l|l|l|l|l|l|l|l|}
\hline $\begin{array}{l}\text { Samples } \\
\text { No. }\end{array}$ & Locality & $\begin{array}{l}\text { Type } \\
\text { of water body }\end{array}$ & Date & $\mathbf{p H}$ & $\mathbf{E h}, \boldsymbol{\mu S}$ & $\mathbf{T e m p},{ }^{\circ} \mathbf{C}$ & $\begin{array}{l}\text { Salinity, } \\
\text { permille }\end{array}$ & $\begin{array}{l}\text { Average } \\
\text { depth (m) }\end{array}$ & Coordinates \\
\hline 79 & Nu-Ålesund & $\begin{array}{l}\text { small pond } \\
\text { (lagoon) }\end{array}$ & 19.08 .15 & 7.07 & $>10,000$ & 6.0 & $>10$ & 0.7 & $\begin{array}{l}78.9159 \mathrm{~N} ; \\
11.9772 \mathrm{E}\end{array}$ \\
\hline 80 & Nu-Ålesund & $\begin{array}{l}\text { small pond } \\
\text { (lagoon) }\end{array}$ & 19.08 .15 & 6.23 & $>10,000$ & 6.8 & $>10$ & 0.4 & $\begin{array}{l}78.9235 \mathrm{~N} ; \\
11.9537 \mathrm{E}\end{array}$ \\
\hline 84 & Grønfjordbreen & puddle & 21.08 .15 & 8.19 & 272 & 7.5 & 0 & 0.5 & $\begin{array}{l}77.9561 \mathrm{~N} ; \\
14.2595 \mathrm{E}\end{array}$ \\
\hline 85 & Grønfjordbreen & puddle & 21.08 .15 & 8.34 & 265 & 7.8 & 0 & 0.5 & $\begin{array}{l}77.9560 \mathrm{~N} ; \\
14.2595 \mathrm{E}\end{array}$ \\
\hline 93 & Grønfjordbreen & puddle & 21.08 .15 & 9.34 & 861 & 11.5 & $\begin{array}{l}>10 \\
\text { (close to } \\
\text { bottom) }\end{array}$ & 0.3 & $\begin{array}{l}77.9637 \mathrm{~N} ; \\
14.2606 \mathrm{E}\end{array}$ \\
\hline 98 & Aldegondabreen & small pond & 22.08 .15 & 8.67 & 487 & 8.8 & 0 & 0.2 & $\begin{array}{l}78.0012 \mathrm{~N} ; \\
14.1710 \mathrm{E}\end{array}$ \\
\hline
\end{tabular}


has long been under study, but our research demonstrates that new findings are still emerging. Most of the found species, including halacarids, are very scarce. Their overall rate of occurrence is represented only by a few specimens, which amount to $7 \%$. Perhaps, this is because they have never been recorded in the Canadian High Arctic (Danks 1981; Bartsch 2011).

\section{Taxonomic structure of Svalbard's non-marine water acarofauna}

Only half of the mite species registeredthose beloning to the marine family Halacaridae - are really water animals. The oribatid mite Ameronothrus lineatus, as well as the members of the gamasid mite subgenus Halolaelaps (Halogamasellus) are usually littoral dwellers (Blaszak and Ehrnsberger 1995; Weigmann 2006; Makarova 2013, 2015b), although Ameronothrus lineatus can penetrate deep inland into the Arctic to populate various tundra habitats (Søvik et al.
2003 and references therein). In Iceland, this species was recorded in a lake (Lindegaard, 1992). Members of the oribatid genus Camisia are mainly typical soil or litter dwellers. Yet Camisia foveolata has also been recorded in moss in spring (Colloff 1993).

No representatives of the large water mite group, Hydrachnidia, Parasitengonina, have been found. As a result, together with two euryhaline halacarid species, Halacarellus subcrispus Bartsch, 1978 and H. subterraneus Schulz, 1933, the combined brackish and freshwater acarofauna of the archipelago presently amounts to no less than seven species: four halacarids, two oribatids, and one gamasid mite. Both of the euryhaline halacarid species mentioned above, which have been recorded in Svalbard by Bartsch (1978), inhabit not only the tidal zone (Bartsch 1978), but also almost fresh brackish water bodies and the near-shore fresh groundwaters (Bartsch 2009).

Table 2

Mite species found in Svalbard water bodies during 2014 and 2015.

New records are marked with asterisk $(*)$

\begin{tabular}{|c|c|c|c|c|}
\hline $\begin{array}{l}\text { Order, } \\
\text { suborder/ } \\
\text { cohort }\end{array}$ & Family & Species & Number, stage & No. of samples \\
\hline \multirow{2}{*}{$\begin{array}{l}\text { Mesostigmata, } \\
\text { Gamasina }\end{array}$} & \multirow{2}{*}{ Halolaelapidae } & \multirow{2}{*}{ Halolaelaps (Halogamasellus) sp. } & 2 deutonymphs & 79 \\
\hline & & & 1 deutonymph & 80 \\
\hline \multirow{3}{*}{$\begin{array}{l}\text { Trombidiformes, } \\
\text { Eupodina }\end{array}$} & \multirow{3}{*}{ Halacaridae } & $\begin{array}{l}\text { Rhombognathides spinipes } \\
\text { (Viets, 1933)* }\end{array}$ & 4 females & 93 \\
\hline & & Isobactrus levis (Viets, 1927)* & 1 female & 93 \\
\hline & & Halacarellus sp. & 1 protonymph & 93 \\
\hline \multirow{4}{*}{$\begin{array}{l}\text { Sarcoptiformes, } \\
\text { Oribatida }\end{array}$} & \multirow{3}{*}{ Crotoniidae } & \multirow{3}{*}{ Camisia foveolata Hammer, 1955} & $\begin{array}{l}11 \text { females, } \\
5 \text { tritonymphs, } \\
3 \text { deutonymphs, } \\
3 \text { protonymphs, } \\
2 \text { larvae }\end{array}$ & 84 \\
\hline & & & $\begin{array}{l}16 \text { females, } \\
12 \text { tritonymphs, } \\
5 \text { deutonymphs, } \\
3 \text { protonymphs, } \\
1 \text { larva }\end{array}$ & 85 \\
\hline & & & 1 tritonymph & 98 \\
\hline & Ameronothridae & Ameronothrus lineatus (Thorell, 1871) & $\begin{array}{l}1 \text { female, } \\
3 \text { larvae }\end{array}$ & 93 \\
\hline
\end{tabular}




\section{Characteristics of the mite species}

The predatory gamasid mite, Halolaelaps (Halogamasellus) sp., possibly is a species new to science. In the seaside areas of Svalbard, two species of this predatory subgenus are known: the littoral North Atlantic H. (H.) gerlachi Hirschmann, 1966 (Makarova 2015b) and a yet undescribed species associated with seabird colonies (Makarova 2013). The specimens from our survey could be linked to neither of the two, being represented solely by nymphs. The sporadic specimens of Halolaelaps (H.) sp. were found in two brackish lagoons near Ny-Ålesund (samples 79 and 80).

The predatory halacarid mite, Halacarellus sp., was represented only by the nymphal stage. Two euryhaline species of this genus have been recorded in Svalbard: H. subcrispus Bartsch, 1978, known from mainland Norway, Svalbard, and Greenland; and the clearly psammobiontic $H$. subterraneus Schulz, 1933, known from the North Atlantic, the Baltic, Svalbard, the Mediterranean, and the Black Seas (Bartsch 2009). Another, a yet unidentified member of the genus has been recorded on a Spitsbergen sandy beach (Bartsch 1978). Most species of Halacarellus are marine (Bartsch 2008). In our Svalbard samples, one protonymph of Halacarellus sp. was found in a brackish puddle in the Grønfjordbreen glacier area (sample 93).

The phytophagous halacarid mite, Isobactrus levis (Viets, 1927), inhabits the eastern and western North Atlantic, the Baltic, Novaya Zemlya (Bartsch 2009), and the Karelian coast of the White Sea (Krivolutsky and Antsiferova 2008). It has been found on tidal algae, in brackish to marine habitats (Sokolov 1952; Bartsch 2009). In our Svalbard material, I. levis was recorded in a brackish puddle in the Grønfjordbreen glacier area (sample 93).

The phytophagous halacarid mite, Rhombognathides spinipes (Viets, 1933), has been recorded in the eastern North Atlantic, the Baltic, Novaya Zemlya (Bartsch 2009), and the Karelian coast of the White Sea (Krivolutsky and Antsiferova 2008; sub Rhombognathus aculeatus Sokolov, 1952). It has been found in the upper and mid-tidal zones, in a freshwater lake, and is possibly also common in saltmarsh areas (Sokolov 1952; Bartsch 2009). In our samples, $R$. spinipes was recorded in a brackish puddle in the Grønfjordbreen glacier area (sample 93).

The oribatid mite, Ameronothrus lineatus (Thorell 1871), is common on Svalbard. This species possesses a mainly arctoboreal distribution pattern, inhabiting the marine littoral throughout the northern Holarctic, but is also known in California (Søvik 2004 and references therein). On Svalbard, the aforementioned mite can be found in the soil up to $0.5 \mathrm{~km}$ off the seashore in tundra habitats (Søvik et al. 2003 and references therein). This mostly algophagous mite* has been considered non-aquatic, meaning it is only tolerant to submergence in water, but is not active when submerged (Schatz and Behan-Pelletier 2008). It is interesting to note that once it has been recorded from a lake at a 10-m depth (Lindegaard 1992). Pfingstl (2017) reckoned A. lineatus among transition species, i.e., occurring in the littoral and terrestrial areas. Its development on Svalbard takes five years (one moult per year) and its reproductive output is low, ca 20 larvae (Søvik and Leinaas 2003; Søvik 2004). In our samples, $A$. lineatus has been recovered from one brackish puddle along the seashore in the Grønfjordbreen glacier area (sample 93).

The comminuting microbio-detritivorous (after Walter and Proctor 2013) oribatid mite, Camisia foveolata Hammer, 1955, is rather common in the Arctic soils, being mostly arctoboreal in distribution (Colloff 1993; Subias 2004; our new data). It usually inhabits the litter and moss carpets, but is also known to inhabit moss that grows in streams (Colloff 1993). Many species of the superfamily Crotonoidea are amphibious or aquatic (BehanPelletier and Eamer 2007 and references therein). One amphibious member of the Crotoniidae proper, Platynothrus peltifer (C.L. Koch, 1839), is known to be a common benthic dweller in montane springs (Schatz and Gerecke 1996). One cannot exclude the possibility that the numerous specimens of Camisia foveolata in our material were submerged in a small temporal puddles formed by quick snow/ice thawing. We recorded them on a moraine in the Grønfjordbreen and in Aldegondabreen glaciers' areas (samples 84, 85 and 98; all from freshwater puddles).

\section{Geographical analysis of the Svalbard fauna of Halacaridae}

Most of the mite species found are representatives of the generally marine family Halacaridae. It is rather hard to discuss the similarities between

\footnotetext{
* There are no particular data on their diet in natural conditions, but $A$. lineatus was found in pure Enteromorpha and cyanobacteria overgrowths (Søvik 2004). It can consume unicellular phycobionts of lichens and in the laboratory it fed upon green and red algae, yeast, ascomycete fungi, cyanobacteria (Schulte 1976).
} 
different insular halacarid faunas in the Arctic because they often include either strictly marine (subtidal, bathyal) species; euryhaline species (i.e., species that occur in shallow sea water, littoral habitats, nearshore fresh groundwaters, brackish and fresh water bodies); or freshwater inhabitants.

Even though the list of littoral, brackish, and freshwater mite species of the archipelago totals nine halacarid species, they have been omitted from the latest catalogues of the terrestrial and freshwater invertebrate fauna of Svalbard (Coulson and Refseth 2004; Coulson 2007; Coulson 2012), as well as from the recent review of its diversity on the Barents Sea archipelagoes (Coulson et al. 2014). These nine species include four non-marine species (Table 3), as well as the marine littoral Bradyagaue alberti (Trouessart, 1902), Copidognathus richardi (Trouessart, 1902), Copidognathus reticulatus (Trouessart, 1893), Rhombognathus subtilis Bartsch, 1975, and Halacarellus sp. (Bartsch 1978, 2009).

Nonetheless, some published information exists concerning the halacarids in the Arctic inland water bodies. All available lists (without individual records though) of euryhaline or freshwater members of the family in the Arctic are presented in Table 3. Of the 12 species found, 10 species have been recorded in two regions. This observation seems to question any existing patterns in this species set. Yet, it is easy to see that truly freshwater species show vast geographical distributions (Holarctic or cosmopolitan).

At present, the list of halacarids found in the marine, tidal and inland habitats of Svalbard totals 13 species: Bradyagaue alberti (Trouessart, 1902); Copidognathus poucheti (Trouessart, 1893); C. reticulatus (Trouessart, 1893); C. richardi (Trouessart, 1902); Halacarellus subcrispus Bartsch, 1978; H. subterraneus Schulz, 1933; Halacarellus sp., Halacarus borealis Trouessart, 1893; Thalassarachna coeca (Trouessart, 1902); T. princeps (Trouessart, 1902); Isobactrus levis (Viets, 1927); Rhombognathides spinipes (Viets, 1933); Rhombognathus subtilis Bartsch, 1975 (Trouessart 1893; Bartsch 1978, 2009; our data).

Table 3

Euryhaline and freshwater species of the family Halacaridae found in the Arctic regions (after Viets 1928; Sokolov 1952; Bartsch 1978, 2009, 2011; Gerecke 2015; new data)

\begin{tabular}{|c|c|c|c|c|c|c|c|}
\hline \multirow[b]{2}{*}{ Species } & \multicolumn{5}{|c|}{ Island/archipelago/region } & \multirow{2}{*}{$\begin{array}{l}\text { Prefe- } \\
\text { rence }\end{array}$} & \multirow[b]{2}{*}{ Area } \\
\hline & $\begin{array}{l}\text { Novaya } \\
\text { Zemlya }\end{array}$ & Svalbard & Greenland & Quebec* & Iceland & & \\
\hline Rhombognathides seahami (Hodge, 1860) & + & & + & & & E & NA, A \\
\hline Rhombognathus notops (Gosse, 1855) & $+?$ & & $+?$ & & & E & eNA, A \\
\hline Halacarellus subcrispus Bartsch, 1978 & & + & + & & & E & NA, A \\
\hline Halacarellus balticus (Lohmann, 1889) & & & + & & & $\mathrm{E}$ & $\mathrm{NA}, \mathrm{A}$ \\
\hline Porolohmannella violacea (Kramer 1879) & & & + & + & & $\mathrm{F}$ & $\mathrm{H}, \mathrm{Pz}$ \\
\hline Soldanellonyx chappuisi Walter, 1917 & & & + & + & & $\mathrm{F}$ & $\mathrm{H}, \mathrm{Pz}$ \\
\hline Isobactrus levis (Viets, 1927) & + & $+* *$ & & & & $\mathrm{E}$ & $\mathrm{NA}, \mathrm{A}$ \\
\hline Rhombognathides spinipes (Viets, 1933) & + & $+* *$ & & & & E & $\mathrm{NA}, \mathrm{A}$ \\
\hline Halacarellus subterraneus Schulz, 1933 & & + & & & & E & $\mathrm{NA}, \mathrm{A}, \mathrm{M}$ \\
\hline $\begin{array}{l}\text { Lobohalacarus weberi } \\
\text { (Romijn and Viets, 1924) }\end{array}$ & & & & + & + & $\mathrm{F}$ & $\mathrm{C}, \mathrm{Pz}$ \\
\hline Porohalacarus alpinus (Thor, 1910) & & & & + & + & $\mathrm{F}$ & $\mathrm{C}, \mathrm{Pz}$ \\
\hline Soldanellonyx monardi Walter, 1919 & & & & + & + & $\mathrm{F}$ & $\mathrm{C}, \mathrm{Pz}$ \\
\hline
\end{tabular}

Notes. *_Lake Matamec, eastern Quebec, forested tundra district; **__new data. Preference-E, euryhaline; F, freshwater. Codes of areas: euryhaline species_eNA, eastern North Atlantic; NA, North Atlantic; A, Arctic; M, Mediterranean; freshwater species- $\mathrm{H}$, Holarctic; C, cosmopolitan; Pz, polyzonal. ?_record requires confirmation (Bartsch 2009). 
This list includes four exclusively marine species (C. poucheti, H. borealis, T. coeca, T. princeps). Another four species live both in marine and littoral habitats (B. alberti, $C$. reticulatus, $C$. richardi, $R$. subtilis). The remaining four species ( $H$. subcrispus, $H$. subterraneus, I. levis, $R$. spinipes) are euryhaline, found among other habitats in brackish and fresh waters as well (Trouessart 1893; Sokolov 1952; Bartsch 2009). Presently, we have no information on the ecology of Halacarellus sp.

Among these 13 species, B. alberti, T. coeca and T. princeps were only found near the Svalbard coast. Seven other species are restricted in their distribution to the North Atlantic (C. poucheti, C. reticulatus, $R$. subtilis, H. borealis and H. subcrispus) or inhabit the North Atlantic, the Baltic, and the White Seas (I. levis, $R$. spinipes). Only two species appear to be eurythermic: $C$. richardi, which dwell in the eastern North Atlantic and the Azores; and H. subterraneus, known from the eastern and western North Atlantic, the Baltic, the Mediterranean, and the Black Seas (Bartsch 2009). Hence, in general, the halacarid mite fauna of the Svalbard region can be described as rather specialized and mainly cryophilic. The nonswimming halacarid mites have very limited dispersion and reproductive capacities (Bartsch 1989, 2008). Nevertheless, we may attribute this conclusion to our still insufficient knowledge.

\section{On the absence of true freshwater mites (Hydrachnidia) from Svalbard}

No members of "true" freshwater mites, the relatively easily visible Hydrachnidia, were found in such High Arctic areas as the main part of Svalbard, Novaya Zemlya, and Franz Josef Land. Their distribution is possibly limited by the heat supply. At the same time, Sperchon brevirostis Koenike, 1895 (Sperchontidae) is known for sure to occur on Bear Island, the southern enclave of the Svalbard Archipelago (references in Coulson and Refseth 2004)*. In the Canadian High Arctic, individual hydrachnid members have regularly been registered. Thus, only one species inhabits either Ellesmere or Devon Islands (neither identified; references in Danks 1981), as well as the northernmost Greenland [Lebertia porosa (Thor, 1900)]. It is interesting to note that further to the south, in Greenland, a total of five hydrachnid species have been recorded (Gerecke 2015). No less than four hydrachnid species live in the Low Arctic landscapes of the Lena River Delta (Semenchenko et al. 2010)

${ }^{*}$ This species, widespread in the western Palaeartcic, is also known from northeastern Greenland (Lettevall 1962). and on Baffin Island (Habeeb 1957). At the border with the taiga zone, in a lake within the Bolshezemelskaya Tundra, up to 24 hydrachnid species have been registered (Tsember 1972). Larval stages of most of these mites parasitize water insects, mainly dipterans (Smith and Oliver 1986). Since their species number increases sharply southward along the latitudinal gradient (Danks 1990), it is possible that the diversity is warmth-dependent and that the warming effect enhances the dispersion of hydrachnids both directly and indirectly.

\section{CONCLUSIONS}

(1) At the bottom of fresh and brackish water bodies of Svalbard, six mite species were found during this survey, namely, the oribatids Camisia foveolata and Ameronothrus lineatus, the gamasid mite Halolaelaps sp., and the halacarids Halacarellus sp., Isobactrus levis and Rhombognathides spinipes. Two species of Halacaridae, I. levis and $R$. spinipes, are new to the Svalbard fauna.

(2) In general, the currently known halacarid mite fauna of the Svalbard area, including euryhaline and marine species, is rather specialized regionally, being mainly cryophilic. This can probably be explained by a rather low exploration level of the High Arctic fauna.

(3) No members of truly freshwater mites (Hydrachnidia) have been identified in such High Arctic area as West Spitsbergen, Svalbard.

\section{ACKNOWLEDGEMENTS}

The expedition to Svalbard was supported by the Research Council of Norway (projects FREMONEC, BRANTA DULCIS) and the Norwegian Institute for Nature Research (NINA). The sampling, the laboratory work with the collected samples, and the definition of the objectives were all supported by the Program "Scientific bases for the creation of a national depository bank of living systems" of the Russian Science Foundation, project No. 14-5000029. The study on the taxonomy and biogeography of Acari was financially supported by the Russian Foundation for Basic Research, project No. 17-04-01603. The valuable help of S.I. Golovatch in improving the English text is highly appreciated. Our Norwegian colleagues, B. Walseng and I. Dimante-Deimantovica, provided us with valuable comments on an early manuscript draft. K.V. Makarov assisted with the prepartion of the map of the collecting localities on Svalbard. We are most grateful to all those bodies and colleagues. 


\section{REFERENCES}

Bartsch, I. 1978. Halacaridae (Acari) von Gezeitenstränden Nordnorwegens. Mikrofauna des Meeresbodens, 70: 1-22.

Bartsch, I. 1989. Marine mites (Halacaroidea: Acari): a geographical and ecological survey. Hydrobiologia, 178: 21-42.

Bartsch, I. 2006a. Acari: Halacaroidea. In: R. Gerecke (Ed.). Süßwasserfauna von Mitteleuropa 7/2-1, Chelicerata: Araneae, Acari I. Elsevier, Spektrum, Heidelberg, pp. 113-157.

Bartsch, I. 2006b. Halacaroidea (Acari): a guide to marine genera. Organisms, Diversity and Evolution, 6, Electronic Supplement, 6: 1-104.

Bartsch, I. 2008. Global diversity of halacarid mites (Halacaridae: Acari: Arachnida) in freshwater. Hydrobiologia, 595: 317-322.

Bartsch, I. 2009. Checklist of marine and freshwater halacarid mite genera and species (Halacaridae: Acari) with notes on synonyms, habitats, distribution and descriptions of the taxa. Zootaxa, 1998: $170 \mathrm{pp}$.

Bartsch, I. 2011. North American freshwater Halacaridae (Acari): literature survey and new records. International Journal of Acarology, 37: 490-510.

Behan-Pelletier, V.M. and Eamer, B. 2007. Aquatic Oribatida: adaptations, constraints, distribution and ecology. In: J.B. Moreas et al. (Eds.). Acarology XI: Proceedings of the International Congress. Instituto de Biología and Facultad de Ciencias, Universidad Nacional Autónoma de México, Sociedad Latinoamericana de Acarología, México, pp. 71-82.

Blaszak, C. and Ehrnsberger, R. 1998. Eine neue Untergattung Haloseius subgen. nov. in der Gattung Halolaelaps Berlese and Trouessart, 1889 (Acari: Gamasida: Halolaelapidae). Genus, 9: 421-429.

COAT web portal - Climate-ecological Observatory for Arctic Tundra. http://www.coat.no.

Colloff, M.J. 1993. A taxonomic revision of the oribatid mite genus Camisia (Acari: Oribatida). Journal of Natural History, 27: 1325-1408.

Coulson, S. 2007. Terrestrial and freshwater invertebrate fauna of the High Arctic archipelago of Svalbard. Zootaxa, 1448: 41-58.

Coulson, S. 2012. The Terrestrial and Freshwater Iinvertebrate Fauna of Svalbard: an Inventory and Bibliography. Norsk Polarinstitutt Skrifter, Tromsø, $98 \mathrm{pp}$.

Coulson, S.J. and Refseth, D. 2004. The terrestrial and freshwater invertebrate fauna of Svalbard (and Jan Mayen). In: P. Prestud, H. Strøm, and H.A. Goldman (Eds.). A Catalogue of the Terrestrial and Marine Animals of Svalbard. Tromsø. Norwegian Polar Institute, Oslo, pp. 75-122.
Coulson, S.J., Convey, P., Aakra, K., Aarvik, L., ÁvilaJiménez, M.L., Babenko, A., Biersma, E., Boström, S., Brittain, J., Carlsson, A., Christoffersen, K.S., De Smet, W.H., Ekrem, T., Fjellberg, A., Fuereder, L. Gustafsson, D., Gwiazdowicz, D.J., Hågvar, S., Hansen, L.O., Kaczmarek, L., Kolicka, M., Kuklin, V., Lakka, H-K., Lebedeva, N., Makarova, O., Maraldo, K., Melekhina, E., Ødegaard, F., Pilskog, H.E., Simon, J.C., Sohlenius, B., Solhøy, T., Søli, G., Stur, E., Tanaevitch, A., Taskaeva, A., Velle, G. and Zmudczyńska, K. 2014. The terrestrial and freshwater invertebrate biodiversity of the archipelagoes of the Barents Sea; Svalbard, Franz Josef Land and Novaya Zemlya. Soil Biology and Biochemistry, 68: 440-470.

Danks, H.V. 1981. Arctic Arthropods. A Review of Systematics and Ecology with Particular Reference to the North America Fauna. Entomological Society of Canada, Ottawa, 608 pp.

Danks, H.V. 1990. Arctic insects: Instructive diversity. In: C.R. Harington (Ed.). Canada's Missing Dimension: Science and History in the Canadian Arctic Islands 2. Canadian Museum of Nature, Ottawa, pp. 444-470.

Dolgushin, L.D. and Osipova, G.B. 1989. The Nature of the World: Glaciers. [Priroda Mira. Ledniki]. Mysl, Moscow, 447 pp. [In Russian]

Gerecke, R. 2015. Hydrachnidia and Halacaridae (Water mites). In: J. Böcher, N.P. Kristensen, T. Pape and L. Vilhelmsen (Eds.). The Greenland Entomofauna. An Identification Manual of Insects, Spiders and their Allies. 5. Brill, Leiden, pp. 790-801.

Habeeb, H. 1957. Some water mites from Baffin Island. Leaflets of Acadian Biology, 13: 2.

Hisdal, V. 1998. Svalbard. Nature and History. Polarhåndbok. Norwegian Polar Institute, Oslo, 75 pp.

Janiec, K. 1996. The comparison of freshwater invertebrates of Spitsbergen (Arctic) and King George Island (Antarctic). Polish Polar Research, 17 (34): 173-202.

Krivolutsky, D.A. and Antsiferova, M.P. 2008. Podclass Acari Leach 1817, kleshchi. Otryad Acariformes Zachvatkin 1952. In: E.D. Krasnova, A.V. Tchesunov, N.M. Kalyakina and E.N. Bubnova (Eds.). A Catalogue of the Biota of the White Sea Biological Station of the Moscow State University. KMK Scientific Press, Moscow, pp. 318-324. [In Russian]

Lettevall, U. 1962 On the Hydracarina of Greenland with a description of Lebertia (Pseudolebertia) groenlandica n. sp. Meddelelser om Grønland, 170 (1): $1-40$.

Lindegaard, C. 1992. Zoobenthos ecology of Thingvallavatn: vertical distribution, abundance, population dynamics and production. Oikos, 64: 257-304. 
Makarova, O.L. 2013. Gamasid mites (Parasitiformes, Mesostigmata) of the European Arctic and their distribution patterns. Entomological Review, 93 (1): 113-133.

Makarova, O.L. 2015a. Acari. In: J. Böcher, N.P. Kristensen, T. Pape and L. Vilhelmsen (Eds.). The Greenland Entomofauna. An Identification Manual of Insects, Spiders and their Allies. Brill, Leiden, pp. 705-856.

Makarova, O.L. 2015b. The fauna of free-living mites (Acari) of Greenland. Entomological Review, 95 (1): 108-125.

Mokievsky, V. 2009. Ecology of Marine Meiobenthos. KMK Scientific Press, Moscow, 286 pp. [In Russian]

Motas, C. 1961. Hydrachnellae. Zoology of Iceland, 3 (56): 1-26.

Nordly, P.Ø. 2005. Long-term temperature trends and variability at Svalbard (1911-2004). Geophysics Research Abstracts, 7 (06939): 142-153.

Pechurov, L.V. 1983. Spitzbergen. Mysl, Moscow, 150 pp. [In Russian]

Pfingstl, T. 2017. The marine-associated lifestyle of ameronothroid mites (Acari, Oribatida) and its evolutionary origin: a review. Acarologia, 57 (3): 693-721.

Pienitz, R., Doran, T. and Lamoureux, S.F. 2008. Origin and geomorphology of lakes in the polar regions. In: W.F. Laybourn-Parry and J. Vincent (Eds.). Polar Lakes and Rivers. Oxford University Press, New York, pp. 25-41.

Schatz, H. and Behan-Pelletier, V. 2008. Global diversity of oribatids (Oribatida: Acari: Arachnida). Freshwater Animal Diversity Assessment. Hydrobiologia, 595: 317-322.

Schatz, H. and Gerecke, R. 1996. Hornmilben (Acari, Oribatida) aus Quellen und Quellbaechen im Nationalpark Berchtesgaden (Oberbayern) und in den Suedlichen Alpen (Trentino - Alto Adige). Bericht Naturwissenschaftlichmedizinischen Vereins Innsbruck, 83: 121-144.

Schulte, G. 1976. Zur Nahrungsbiologie der terrestrischen und marinen Milbenfamilie Ameronothridae (Acari, Oribatei). Pedobiologia, 16: 332-352.

Semenchenko, K.A., Abé, H. and Boeskorov, G.G. 2010. New data on the water mite fauna (Acari, Hydrachnidia, Halacaroidea) of the Sakha Repub- lic (Yakutia). Zoologicheskii Zhurnal, 89: 167-177. [In Russian]

Smith, I.M. and Oliver, D.R. 1986. Review of parasitic associations of larval water mites (Acari: Parasitengona: Hydrachnida) with insect hosts. Canadian Entomologist, 118: 407-472.

Sokolov, I.I. 1952. Vodyanye Kleshchi. Chast II. Halacarae [Water mites. Part 2. Halacarae]. Fauna SSSR, 5 (2). Izdatelstvo Akademii Nauk SSSR, Moscow-Leningrad, 201 pp. [In Russian]

Søvik, G. 2004. The biology and life history of arctic populations of the littoral mite Ameronothrus lineatus (Acari, Oribatida). Experimental and Applied Acarology, 34: 3-20.

Søvik, G. and Leinaas, H.P. 2003. Adult survival and reproduction in an arctic mite, Ameronothrus lineatus (Acari, Oribatida): effects of temperature and winter cold. Canadian Journal of Zoology, 81: 1579-1588.

Søvik, G., Leinaas, H.P., Ims, R.A. and Sølhoy, T. 2003. Population dynamics and life history of the oribatid mite Ameronothrus lineatus (Acari, Oribatida) of the high arctic archipelago of Svalbard. Pedobiologia, 47: 257-271.

Subías, L.S. 2004. Listado sistemático, sinonimico y biogeográfico de los ácaros oribátidos (Acariformes, Oribatida) del mundo (1758-2002). Graellsia, 60 (numero extraordinario): 3-305.

Trouessart, E. 1893. Note sur les acariens recueillis au Spitzberg pendant le voyage de la Manche. Nouvelles Archives des Missions Scientifiques Littéraires, 5: 255-263.

Tsember, O.S. 1974. Water mites (Hydracarina) of the Bolshoy Kharbey Lake. Biologicheskiye Issledovaniya na Severo-vostoke Evropeyskoy Chasti SSSR. Ezhegodnik, 1973: 166-170. [In Russian]

Viets, K. 1928. Halacaridae von der Murman-Küste, aus dem Weissen Meer und von Nowaja-Semlja. Issledovaniya Morey SSSR, 6: 81-88. [In Russian and German]

Walter, D.E. and Proctor, H.C. 2013. Mites: Ecology, Evolution and Behaviour. Life at a Microscale. $2^{\text {nd }}$ edn. Springer, Dordrecht-Heidelberg-New YorkLondon, 494 pp.

Weigmann, G. 2006. Hornmilben (Oribatida). Die Tierwelt Deutschlands 76. Goecke and Evers, Keltern, $520 \mathrm{pp}$. 